\title{
GENETIC DIVERSITY FOR HEAT TOLERANCE IN SOME BREAD WHEAT GENOTYPES UNDER UPPER EGYPT CONDITIONS
}

\author{
TAWFELIS, M. B. ${ }^{1}$, K. A. A. KHIERALLA ${ }^{2}$, M. A. EL MORSHIDY ${ }^{2}$ \\ AND Y. M. FELTAOUS ${ }^{1}$ \\ 1. Field Crops Res. Inst., ARC, Giza, Egypt \\ 2. Agronomy Dept., Fac. of Agric., Assiut Univ., Egypt.
}

(Manuscript received 23 May 2011)

\begin{abstract}
The present investigation was carried out at Shandaweel Agricultural Research Station, Agricultural Research Center, Egypt, during the three successive seasons from $2004 / 2005$ to $2006 / 2007$. The objectives of the this investigation were to evaluate some bread wheat genotypes under heat stress conditions in Upper Egypt and to identify the most stable genotypes under these conditions. Twelve bread wheat genotypes (Triticum aestivum $L$ ) were evaluated under nine environments which are the combination among three sowing dates i.e. $25^{\text {th }}$ November, $10^{\text {th }}$ December and $25^{\text {th }}$ December during the three winter growing seasons. Randomized completed block design was used for every planting date. The studied characters included days to physiological maturity, plant height, peduncle length, flag leaf area and straw yield ( $t / h a)$. Performance of the twelve wheat genotypes showed different responses to the different environments. The combined analysis of variance showed highly significant differences among planting dates and genotypes for all studied traits. Delaying sowing date reduced days to physiological maturity, plant height, peduncle length, flag leaf area, and straw yield in the second and third planting dates by an average of $(6.63$ \&14.00\%), (3.85 \& 10.33\%), (6.85 \& 20.21\%), (14.45 \& $23.59 \%)$ and $(17.37 \& 29.76 \%)$, respectively, compared with the recommended sowing date. The joint regression analysis of variance indicated highly significant differences among genotypes for all studied characters. Moreover, partitioning mean of squares due to environments plus genotypes $x$ environments interactions as indicated by $E+(G \times E)$ to the following items $E$ (Linear) showed highly significance for all studied traits. Meanwhile GXE component mean squares were highly significant and significant for all studied characters except for peduncle length. The remainder sum of squares were highly significant for all studied characters. Data of heat susceptibility index for straw yield under normal and late sowing dates indicated that six genotypes i.e. Line \# 3, Line \# 7, Line \# 8 Gemmeiza 9, El-Nelin and HD 2501 were tolerant to heat stress (late sowing dates).

Key words: Wheat genotypes, Triticum aestivum, Heat stress, Stability parameters, Heat susceptibility index (HSI).
\end{abstract}

INTRODUCTION

Wheat (Triticum aestivum L.) is the most widely grown cereal crop in the world and it is the main diet for the Egyptian population. Also, it has been considered the first strategic food crop. Therefore, increasing wheat production becomes an important national goal to reduce the gap between wheat production and 
consumption and to reduce wheat imports and save foreign currency. It was anticipated that high and stable wheat yield could be achieved by applying the recommended cultural practices and using high yielding cultivars.

Variations in environment can be divided to two sorts, predictable and unpredictable. The first category includes all permanent characters of the environments, such as general features of the climatic and soil type, as well as these characteristics of the environment which fluctuate in a systematic manner, such as day length. It also includes those aspects of environment that are controlled by man and can be fixed more or less as well, such as planting date, sowing density, methods of harvesting and other agronomic practices. The second category includes fluctuation in weather, such as amount and distribution of rainfall and temperature.

Heat stress is a common abiotic stress that causes stunted plants, reduced tillering, and accelerates plant development leading to small heads, shriveled grains and finally low yields. Respecting agronomic traits affected by this abiotic stress such as days to heading, days to maturity, plant height and grain yield are easily identifiable and can be used as indices for heat tolerance. Understanding the nature of genotype $\mathrm{x}$ environment interaction empowers breeders to test and select more efficient genotypes. Breeding genotypes with wide adaptability has long been a universal goal among plant breeders. To achieve this goal, evaluating breeding lines over time and locations has become an integral part of any plant breeding program. Adaptability and stability performance of cultivars over environments are important for national policy in crop production. Therefore, a grain producer is interested primarily in growing a cultivar with high yield and stability performance at his location.

Several investigators had attempted to estimate $G \times E$ numerically. Two estimates developed by Eberhart and Russell (1966). The first is the regression coefficient $\left(b_{i}\right)$ of a line on environmental indices that estimate its response to favorable conditions while the remainder sums of squares after the regression $\left(S^{2} d_{i}\right)$ illustrate the latter un-described interaction effects. They defined a stable cultivar as one which has a regression coefficient $\left(b_{i}\right)$ equal to 1.0 and with $\left(S^{2} d_{i}\right)$ equal to, or does not deviate significantly from 0.0. Apparently, a cultivar that did not meet both qualifications would be closed as unstable. However, an ideal cultivar would have both, high average performance over a wide range of environments plus stability.

Tawfelis (2006 a) studied the performance and stability of forty bread wheat genotypes under eight environments. The joint regression analysis of variance indicated highly significant differences among genotypes for all studied characters. The heterogeneity of linear responses and remainder sums of squares were highly significant for all traits. The regression coefficient was positively correlated with the 
mean performance indicating that high yielding genotypes had generally, and positive $B_{\mathrm{i}}$ values and revealed a good response to the improving environments.

The objectives of this study were to study the magnitude of $\mathrm{G} x \mathrm{E}$ interactions as well as to assess the stability parameters of morpho-physiological characteristics of twelve bread wheat genotypes under heat stress conditions at Upper Egypt to identify the most stable genotypes under these conditions.

\section{MATERIALS AND METHODS}

The present investigation was conducted at Shandaweel Agricultural Research Station, Agricultural Research Center, Egypt. during 2004/2005 to 2006/2007 growing seasons. However, names, pedigree and origin of the twelve bread wheat genotypes under investigation are presented in Table (1).

Table 1. The name, pedigree and origin of twelve wheat genotypes:-

\begin{tabular}{|c|c|c|c|}
\hline $\begin{array}{l}\text { Ent. } \\
\text { No. }\end{array}$ & Entry name & Pedigree & Origin \\
\hline 1 & Sids 1 & HD2172 / Pavon"s" //1158.57/ Maya 74"s" & Egypt \\
\hline 2 & Giza 168 & Mill / Buc // Seri & Egypt \\
\hline 3 & Line \# 3 & Caza / Kauz // Kauz. & CIMMYT \\
\hline 4 & Sakha 94 & Opata / Rayon // Kauz & Egypt \\
\hline 5 & Line \# 5 & SKAUZ*2/SRIMA & Egypt \\
\hline 6 & Gemmiza \# 10 & $\begin{array}{l}\text { Maya 74"s"/on // 1160-147 /3/ Bb /4/ Chat"s" /5/ Ctow. } \\
\text { Maya"s"/ Crow // Vee"s" }\end{array}$ & Egypt \\
\hline 7 & Line \# 7 & Maya"s"/Mon"s"/4/CMH7.428/MRC//Jup/3/582/5/A2. & CIMMYT \\
\hline 8 & Line \# 8 & $\begin{array}{l}\text { Sakha8/6/Sakha69 } \\
\text { Ald"s"/ Huac"S" //CMH74A.630/5x }\end{array}$ & CIMMYT \\
\hline 9 & Gemmiza \# 9 & $\mathrm{~S} 948 . \mathrm{A}_{1} / 7 * \mathrm{STE}$ & Egypt \\
\hline 10 & El-Nelin & -------- & Sudan \\
\hline 11 & Debeira & -------- & Sudan \\
\hline 12 & HD2501 & & India \\
\hline
\end{tabular}

Sowing dates were $25^{\text {th }}$ November, $10^{\text {th }}$ and $25^{\text {th }}$ December in the three seasons, respectively. The experimental design was randomized complete blocks (RCBD), with three replications for each planting date. The plot size was $3.5 \mathrm{~m}$ long with $2.4 \mathrm{~m}$ width $\left(3.5 \times 2.4=8.4 \mathrm{~m}^{2}\right)$. Each plot included 12 rows, $20 \mathrm{~cm}$ apart between rows and seeds were spaced $5 \mathrm{~cm}$. within rows. The recommended cultural practices of wheat production were applied all over the growing seasons. 


\section{Data were recorded for five characteristics as following}

1 - Days to physiological maturity (MD), the number of days from sowing to physiological maturity.

2- Plant height in $\mathrm{cm}(\mathrm{PLH})$, measured from surface of the soil to the top of the spike of ten main stems taken at random from each experimental plot.

3- Peduncle length in $\mathrm{cm}(\mathrm{PL})$, the top internode length of the main stem at maturity of ten main stems taken at random from each experimental plot.

4-Flag leaf area in $\mathrm{cm}^{2}$ (FLA), ten flag leaves at anthesis were taken at random from each plot and FLA is computed according to the formula of Montgomery (1911), where leaf area $=0.75 \times$ (leaf length $\times$ leaf width at the broadest place).

5- Straw yield in $\mathrm{t} / \mathrm{ha}$ (SY), obtained by weighing all the harvested plants in ton (biological yield) subtracting from the grain yield of harvested area, for each plot.

\section{Meteorological Data}

The monthly mean temperature differed from season to another (Table 2). The mean of maximum and minimum temperatures from the date of sowing to booting, booting to heading and heading to maturity of favorable and late sowing dates (heat stress) are summarized in Table (2). The differences in the maximum temperature at Sohag between late and favorable sowing dates were $0.1{ }^{\mathrm{C}}, 1.87^{\mathrm{C}}$ and $2.06^{\mathrm{C}}$ during sowing to booting, booting to heading and heading to maturity, respectively.

Table 2. Mean maximum (Mix) and minimum (Min) air temperature $\left({ }^{C}\right)$ during growth stage in normal and late sowing date at Sohag Governorate.

\begin{tabular}{|c|c|c|c|c|c|c|}
\hline \multirow{2}{*}{ Months } & \multicolumn{2}{|c|}{$\mathbf{2 0 0 4}$ / 2005 } & \multicolumn{2}{c|}{$\mathbf{2 0 0 5} / \mathbf{2 0 0 6}$} & \multicolumn{2}{c|}{$\mathbf{2 0 0 6} / \mathbf{2 0 0 7}$} \\
\cline { 2 - 7 } & Max & Min & Max & Min & Max & Min \\
\hline \multirow{2}{*}{ November } & 27.90 & 11.50 & 25.90 & 10.00 & 24.03 & 10.69 \\
December & 22.10 & 6.60 & 23.40 & 9.00 & 21.34 & 6.88 \\
January & 20.20 & 5.40 & 21.50 & 6.80 & 19.33 & 5.16 \\
February & 23.30 & 7.60 & 23.50 & 8.90 & 27.48 & 8.52 \\
March & 25.60 & 9.40 & 26.60 & 11.00 & 27.68 & 11.29 \\
April & 36.80 & 16.20 & 30.10 & 14.60 & 34.67 & 21.63 \\
\hline
\end{tabular}

Sowing dates sowing to booting first booting to heading heading to maturity

$\begin{array}{ccccccr} & \text { Max } & \text { Min } & \text { Max } & \text { Min } & \text { Max } & \text { Min } \\ \text { Optimum } & 22.31 & 7.38 & 24.76 & 08.34 & 27.48 & 11.30 \\ \text { Late } & 22.41 & 7.08 & 26.63 & 10.56 & 29.54 & 13.36\end{array}$




\section{Statistical analysis}

Data were subjected to the standard analysis of variance and the combined analysis of variance over nine environments according to Gomez and Gomez (1984) and stability parameters were estimated by the method described by Eberhart and Russell (1966).

A stress-susceptibility index (S) was used to characterize each genotype in the stress environments and the index was calculated using genotype means and a generalized formula (Fischer and Maurer 1978) in which $S=(1-Y D / Y P) / D$, were $Y D=$ mean yield in stress environment, $Y P=$ potential yield in normal environment, $D=$ environment stress intensity $=1$-(mean $Y D$ of all genotypes $/$ YP of all genotypes).

\section{RESULTS AND DISCUSSION}

The combined analysis of variance showed highly significant differences among years for days to physiological maturity, plant height, peduncle length, flag leaf area, and straw yield (Table 3). These results reflect the wide differences in climatic conditions prevailing during the growing seasons. The main effect of sowing dates was highly significant for all studied traits. The studied genotypes had also highly significant differences for all traits, reflecting the wide genetic diversity. The first order interaction of years $x$ dates differed significantly for all traits except for plant height, indicating the different influences of climatic conditions on sowing date. On the other hand, significant interaction between years $x$ genotypes was found for all traits. The combined analysis of variance showed significant interaction between genotypes and sowing dates for all studied traits except for peduncle length, and straw yield (Table 3). Accordingly, there were a differential response between genotypes to sowing dates and years. These results indicate that wheat genotypes responded differently to the different environmental conditions suggesting the importance of assessment of genotypes under different environments in order to identify the best genetic make up for a particular environment. Similar results were obtained by Kheiralla et. al. (1997), Abdel-Shafi et. al. (1999), El-Morshidy et. al. (2001), Tammam and Tawfelis (2004)), Tawfelis (2006) and Al-Otayk (2010). 
Table 3. Mean squares of the combined analysis of variance for the studied characters over all sowing dates and seasons.

\begin{tabular}{|c|c|c|c|c|c|c|}
\hline \multirow[b]{2}{*}{$\begin{array}{l}\text { Source of } \\
\text { variation }\end{array}$} & \multirow[b]{2}{*}{ D.F } & \multicolumn{5}{|c|}{ Mean squares (M.S.) } \\
\hline & & $\begin{array}{l}\text { Days to } \\
\text { maturity }\end{array}$ & $\begin{array}{c}\text { Plant } \\
\text { height } \\
\text { "cm" }\end{array}$ & $\begin{array}{c}\text { Peduncle } \\
\text { length } \\
\text { "cm" }\end{array}$ & $\begin{array}{c}\text { Flag leaf } \\
\text { area "cm² " }\end{array}$ & $\begin{array}{c}\text { Straw } \\
\text { yield } \\
\text { "ton/ha" }\end{array}$ \\
\hline $\operatorname{Year}(Y)$ & 2 & $526.30 * *$ & $92.23 *$ & $254.03 * *$ & $718.32 * *$ & $101.70 * *$ \\
\hline Rep./Y (Error a) & 6 & 5.61 & 18.56 & 8.01 & 4.04 & 3.85 \\
\hline Dates (D) & 2 & $11092.2 * *$ & $3115.59 * *$ & $1744.54 * *$ & $3691.26 * *$ & $490.72 * *$ \\
\hline$Y X D$ & 4 & $213.44 * *$ & 29.12 & $50.35 * *$ & $79.70 * *$ & $23.89 * *$ \\
\hline Error $b$ & 12 & 4.95 & 17.51 & 6.41 & 10.78 & 1.75 \\
\hline Genotypes(G) & 11 & $77.33 * *$ & $1243.83 * *$ & $143.46 * *$ & $658.63 * *$ & $6.87^{* *}$ \\
\hline$Y \times G$ & 22 & $23.94 * *$ & $51.21 * *$ & $26.12^{* *}$ & $13.21 *$ & $5.39 * *$ \\
\hline$D \times G$ & 22 & $8.96 * *$ & $22.55 * *$ & 6.39 & $56.31 * *$ & 1.17 \\
\hline$Y \times D \times G$ & 44 & $4.59 * *$ & $20.53 * *$ & $9.85 * *$ & 5.98 & 2.25 \\
\hline Pooled error & 198 & 2.20 & 10.39 & 4.17 & 7.49 & 1.52 \\
\hline
\end{tabular}

* and ** Significant and highly significant at 0.05 and 0.01 levels of probability, respectively.

\section{I) Performance of genotypes}

\section{(1) Days to physiological maturity}

The performance of the studied genotypes in the nine environments are presented in (Table 4).Sakha 94 cultivar was the earliest in physiological maturity in the three planting dates, while the cultivar Debeira was the latest in physiological maturity in the first sowing date. Meanwhile, line \# 7 was the latest in physiological maturity in the second and third sowing dates. It is clear that Sakha 94 was the earliest in physiological maturity in the $1^{\text {st }}, 2^{\text {nd }}$ and $3^{\text {rd }}$ sowing dates although it was the latest in number of days to heading.

The average number of days to maturity over all environments ranged from 131.26 days for Sakha 94 to 137.11 days for Line \# 7 with an average of 134.73 days. These results indicated that genotypes Giza 168, Line \# 3, Sakha 94, Line\# 5 and ElNelin are earlier in maturity than the grand mean over all environments under Upper Egypt conditions.

It is clear that, late planting date reduced number of days to maturity in the second and third planting dates by an average of 6.63 and $14.00 \%$, respectively, compared to the optimum planting date. These findings are also in agreement with the results obtained by Ismail (1995), Abdel-Shafi et al (1999) and Seleem (2007). 


\section{(2) Plant height (cm)}

Gemmeiza 10 was the shortest one of plant height in the three planting dates, while the cultivar Sids1 was the tallest of plant height in the first and second sowing dates, respectively. Meanwhile, cultivar Gemmeiza 9 was the tallest of plant height in the third sowing date (Table 4).

The average of plant height over all environments ranged from $88.67 \mathrm{~cm}$ for Gemmeiza 10 to $106.30 \mathrm{~cm}$ for Sids 1 with an average of $97.99 \mathrm{~cm}$.

It is clear that, late planting dates caused a reduction in plant height in the second and third planting dates by an average of 3.85 and $10.33 \%$, respectively as compared with the optimum planting date. These results are in harmony with those obtained by Ismail (1995), Sial et. al. (2005) and Seleem (2007).

\section{(3) Peduncle length $(\mathrm{cm})$}

The performance of the studied bread wheat genotypes in the nine environments are presented in (Table 4). Line \# 3 was the shortest one of peduncle length in the three planting dates, while the cultivar El-Nelin was the tallest of peduncle length in the first, second and third planting dates, respectively. 
Table 4. Means number of days to physiological maturity, plant height $(\mathrm{cm})$ and peduncle length $(\mathrm{cm})$ of the twelve bread wheat genotypes under three planting dates over all seasons.

\begin{tabular}{|c|c|c|c|c|c|c|c|c|c|c|c|c|c|c|c|c|c|c|}
\hline \multirow[b]{2}{*}{ Genotype } & \multicolumn{6}{|c|}{ Physiological maturity } & \multicolumn{6}{|c|}{ Plant Height $(\mathrm{cm})$} & \multicolumn{6}{|c|}{ Peduncle length $(\mathrm{cm})$} \\
\hline & $D 1$ & $D 2$ & D 3 & Mean & $\begin{array}{c}\text { Red. } \\
\text { \% } \\
D 2\end{array}$ & $\operatorname{Red,\% }_{D 3} \%$ & $D 1$ & $D 2$ & $D 3$ & Mean & $\begin{array}{c}\text { Red. } \\
o \% \\
D 2\end{array}$ & $\begin{array}{c}\text { Red. } \\
\% \% \\
D 3\end{array}$ & $D 1$ & $D 2$ & $D 3$ & $\underset{n}{M e a}$ & $\begin{array}{c}\text { Red. } \\
\text { O\% } \\
\text { D2 }\end{array}$ & $\begin{array}{c}\text { Red. } \\
\text { o } \\
\text { D3 }\end{array}$ \\
\hline Sids 1 & 145.56 & 137.11 & 125.22 & 135.96 & 5.81 & 13.97 & 112.44 & 107.22 & 99.22 & 106.30 & 4.64 & 11.76 & 40.56 & 36.29 & 30.81 & 35.90 & 10.53 & 24.04 \\
\hline Giza 168 & 143.44 & 134.00 & 123.44 & 133.63 & 6.58 & 13.94 & 98.67 & 93.67 & 90.56 & 94.30 & 5.07 & 8.22 & 41.14 & 37.57 & 33.91 & 37.53 & 8.68 & 17.57 \\
\hline Line \# 3 & 143.56 & 134.11 & 122.67 & 133.45 & 6.58 & 14.55 & 96.56 & 94.11 & 86.44 & 92.37 & 2.54 & 10.48 & 35.06 & 31.75 & 25.41 & 30.74 & 9.44 & 27.52 \\
\hline Sakha 94 & 140.67 & 132.00 & 121.11 & 131.26 & 6.16 & 13.90 & 109.56 & 105.78 & 95.00 & 103.44 & 3.45 & 13.29 & 39.81 & 38.03 & 31.52 & 36.42 & 4.47 & 20.83 \\
\hline Line \# 5 & 144.89 & 133.33 & 123.78 & 134.00 & 7.98 & 14.57 & 98.67 & 94.11 & 86.89 & 93.22 & 4.62 & 11.94 & 37.16 & 35.72 & 27.97 & 33.62 & 3.88 & 24.47 \\
\hline Gemmeiza 10 & 146.11 & 137.56 & 127.00 & 136.89 & 5.85 & 13.08 & 92.22 & 89.67 & 84.11 & 88.67 & 2.77 & 8.79 & 36.83 & 34.08 & 28.36 & 33.12 & 7.47 & 23.00 \\
\hline Line \# 7 & 145.33 & 137.67 & 128.33 & 137.11 & 5.27 & 11.70 & 93.00 & 92.89 & 85.00 & 90.30 & 0.12 & 8.60 & 38.34 & 35.97 & 29.89 & 34.74 & 6.18 & 22.04 \\
\hline Line \# 8 & 145.00 & 135.89 & 126.44 & 135.78 & 6.28 & 12.80 & 96.89 & 94.33 & 84.44 & 91.89 & 2.64 & 12.85 & 38.46 & 36.40 & 31.08 & 35.31 & 5.36 & 19.19 \\
\hline Gemmeiza 9 & 145.11 & 137.44 & 125.22 & 135.93 & 5.29 & 13.71 & 110.67 & 104.78 & 100.78 & 105.41 & 5.32 & 8.94 & 39.31 & 36.43 & 33.16 & 36.30 & 8.19 & 15.64 \\
\hline EI-Nelin & 144.67 & 133.56 & 122.78 & 133.67 & 7.68 & 15.13 & 110.89 & 107.00 & 100.56 & 106.15 & 3.51 & 9.32 & 42.55 & 39.75 & 35.40 & 39.23 & 6.58 & 16.80 \\
\hline Debeira & 146.22 & 134.33 & 124.44 & 135.00 & 8.13 & 14.90 & 108.44 & 104.44 & 97.11 & 103.33 & 3.69 & 10.45 & 39.79 & 37.38 & 33.92 & 37.03 & 6.06 & 14.75 \\
\hline$H D 2501$ & 145.56 & 134.00 & 122.56 & 134.04 & 7.94 & 15.80 & 106.33 & 98.67 & 96.67 & 100.56 & 7.20 & 9.08 & 40.62 & 38.50 & 33.56 & 37.49 & 5.22 & 17.38 \\
\hline Average & 144.68 & 135.08 & 124.42 & 134.73 & 6.63 & 14.00 & 102.85 & 98.89 & 92.23 & 97.99 & 3.85 & 10.33 & 39.14 & 36.46 & 31.23 & 35.62 & 6.85 & 20.21 \\
\hline $\begin{array}{l}\text { L.C. D } \\
\text { Years } \\
\text { Dates } \\
\text { Genotype } \\
\text { Y X D } \\
\text { Y XG } \\
\text { D XG } \\
\text { Y X D X G }\end{array}$ & & $\begin{array}{l}0.05 \\
0.57 \\
0.57 \\
0.70 \\
0.98 \\
1.24 \\
1.41 \\
3.04\end{array}$ & & $\begin{array}{l}0.01 \\
0.77 \\
0.77 \\
0.91 \\
1.33 \\
1.62 \\
1.85 \\
4.05\end{array}$ & & & $\begin{array}{l}\text { L. C. D } \\
\text { Years } \\
\text { Dates } \\
\text { Genotype } \\
\text { Y X D } \\
\text { Y X G } \\
\text { D X G } \\
\text { Y X D X G }\end{array}$ & & $\begin{array}{l}.05 \\
.07 \\
.53 \\
.15 \\
.05 \\
.83 \\
.37\end{array}$ & $\begin{array}{l}0.01 \\
1.45 \\
1.45 \\
1.97 \\
3.01 \\
4.01 \\
5.17 \\
10.00\end{array}$ & & & & $\begin{array}{l}\text { C. D } \\
\text { ars } \\
\text { tes } \\
\text { enotype } \\
\text { D } \\
\text { G } \\
\text { G } \\
\text { D x G }\end{array}$ & $\begin{array}{l}0.05 \\
0.64 \\
0.64 \\
0.97 \\
1.25 \\
1.84 \\
3.16 \\
3.83\end{array}$ & & $\begin{array}{l}0.01 \\
0.88 \\
0.88 \\
1.25 \\
1.76 \\
2.40 \\
4.57 \\
5.07\end{array}$ & \\
\hline
\end{tabular}


Table 5. Means flag leaf area (cm2) and strew yield ( $\mathrm{t} / \mathrm{ha})$ of the twelve bread wheat genotypes under three planting dates over all seasons.

\begin{tabular}{|c|c|c|c|c|c|c|c|c|c|c|c|c|}
\hline \multirow{2}{*}{ Genotype } & \multicolumn{6}{|c|}{ Flag Leaf area $\left(\mathrm{cm}^{2}\right)$} & \multicolumn{6}{|c|}{ Straw yield (t/ha) } \\
\hline & $D 1$ & D 2 & $D 3$ & Mean & $\operatorname{Red}_{\mathrm{D} 2} \%$ & $\operatorname{Red}_{D 3} \%$ & $D 1$ & $D 2$ & $D 3$ & Mean & Red.\% D2 & $\operatorname{Red,\% }_{\mathrm{D}} \%$ \\
\hline Sids 1 & 59.01 & 49.47 & 39.24 & 49.12 & 16.17 & 33.50 & 15.64 & 13.05 & 10.82 & 13.17 & 16.56 & 30.82 \\
\hline Giza 168 & 46.88 & 38.59 & 35.73 & 40.40 & 17.68 & 23.78 & 13.45 & 10.78 & 9.33 & 11.19 & 19.85 & 30.63 \\
\hline Line \# 3 & 41.75 & 36.32 & 34.73 & 37.60 & 13.01 & 16.81 & 13.59 & 11.30 & 9.93 & 11.61 & 16.85 & 26.93 \\
\hline Sakha 94 & 42.08 & 37.13 & 33.80 & 37.67 & 11.76 & 19.68 & 14.39 & 11.83 & 9.54 & 11.92 & 17.79 & 33.70 \\
\hline Line \# 5 & 46.96 & 40.87 & 36.89 & 41.57 & 12.97 & 21.44 & 13.94 & 12.24 & 9.76 & 11.98 & 12.20 & 29.99 \\
\hline Gemmeiza 10 & 43.10 & 38.13 & 34.11 & 38.45 & 11.53 & 20.86 & 14.79 & 11.29 & 10.16 & 12.09 & 23.66 & 31.30 \\
\hline Line \# 7 & 40.88 & 35.62 & 30.79 & 35.76 & 12.87 & 24.68 & 14.07 & 11.99 & 10.18 & 12.08 & 14.78 & 27.65 \\
\hline Line \# 8 & 43.92 & 35.50 & 33.87 & 37.76 & 19.17 & 22.88 & 14.28 & 12.13 & 10.11 & 12.17 & 15.06 & 29.20 \\
\hline Gemmeiza 9 & 44.53 & 37.85 & 35.70 & 39.36 & 15.00 & 19.83 & 14.68 & 12.49 & 10.63 & 12.60 & 14.92 & 27.59 \\
\hline EI-Nelin & 47.73 & 45.26 & 41.08 & 44.69 & 5.17 & 13.93 & 13.72 & 11.35 & 9.73 & 11.59 & 17.27 & 29.08 \\
\hline Debeira & 54.11 & 44.61 & 38.68 & 45.80 & 17.56 & 28.52 & 15.12 & 11.48 & 9.98 & 12.19 & 24.07 & 33.99 \\
\hline HD2501 & 58.80 & 48.07 & 40.73 & 49.20 & 18.25 & 30.73 & 13.65 & 11.67 & 10.22 & 11.85 & 14.51 & 25.13 \\
\hline Average & 47.48 & 40.62 & 36.28 & 41.46 & 14.45 & 23.59 & 14.28 & 11.80 & 10.03 & 12.04 & 17.37 & 29.76 \\
\hline $\begin{array}{l}\text { L.C. D } \\
\text { Years } \\
\text { Dates } \\
\text { Genotype } \\
\text { Y X D } \\
\text { Y X G } \\
\text { D X G } \\
\text { Y X D X G }\end{array}$ & & $\begin{array}{l}0.05 \\
0.84 \\
0.84 \\
1.30 \\
1.63 \\
3.26 \\
2.46 \\
9.05\end{array}$ & & $\begin{array}{l}0.01 \\
1.14 \\
1.14 \\
1.68 \\
2.28 \\
4.39 \\
3.21 \\
11.24\end{array}$ & & & $\begin{array}{l}\text { L. C. D } \\
\text { Years } \\
\text { Dates } \\
\text { Genotype } \\
\text { Y X D } \\
\text { Y X G } \\
\text { D X G } \\
\text { Y X D X G }\end{array}$ & & $\begin{array}{l}0.05 \\
0.22 \\
0.22 \\
0.53 \\
0.41 \\
0.97 \\
1.70 \\
2.65\end{array}$ & & $\begin{array}{l}0.01 \\
0.30 \\
0.30 \\
0.70 \\
0.57 \\
1.19 \\
2.49 \\
3.77\end{array}$ & \\
\hline
\end{tabular}


The average of peduncle length over all environments ranged from $30.74 \mathrm{~cm}$ for Line \# 3 to $39.23 \mathrm{~cm}$ for El-Nelin with an average of $35.62 \mathrm{~cm}$.

It is clear that, late planting date caused a reduction in peduncle length in the second and third planting dates by an average of 6.85 and $20.21 \%$, respectively compared with the optimum planting date.

\section{(4) Flag leaf area $\left(\mathrm{cm}^{2}\right)$}

Line \# 7 was the lowest one of flag leaf area in the first and third planting dates, respectively, while Line \# 8 was the lowest one of flag leaf area in the third planting date. Meanwhile, the cultivar Sids 1 was the highest of flag leaf area in the first and second sowing dates, respectively, while the cultivar El-Nelin was the highest of flag leaf area in the third planting date (Table 5).

The average of flag leaf area over all environments ranged from $35.76 \mathrm{~cm}^{2}$ for Line \# 7 to $49.20 \mathrm{~cm}^{2}$ for HD 2501 with an average of $41.46 \mathrm{~cm}^{2}$.

It is clear that late planting dates caused a reduction in flag leaf area in the second and third planting dates by an average of 14.45 and $23.59 \%$, respectively, compared with the optimum planting date.

\section{(5) Straw yield ( $t / h a)$}

The performance of the studied bread wheat genotypes in the nine environments are presented in (Table 5). The cultivar Giza 168 was the lowest of straw yield in the three planting dates, respectively, while the cultivar Sids 1 was the highest of straw yield in the three planting dates, respectively.

The average of straw yield over all environments ranged from $11.19 \mathrm{t} / \mathrm{ha}$ for Giza 168 to $13.17 \mathrm{t} /$ ha for Sids 1 with an average of $12.04 \mathrm{t} / \mathrm{ha}$. These results indicated that Sids 1and Gemmeiza 9 produced the highest straw yield compared with the grand mean over all environments under Upper Egypt conditions.

It is clear that, late planting caused a reduction in straw yield in the second and third planting dates by an average of 17.37 and $29.76 \%$, respectively as compared with the optimum planting date. Similar results were obtained by Ismail (1995) and Tammam and Tawfelis (2004).

\section{II) Genotype $x$ environment interaction and stability analysis}

The impact of genotype by environment interaction (GXE) on the relative performance and stability of a genotype across environments is so important that it forms challenging difficulty to the breeder in developing superior cultivars broadly adapted (Eberhart and Russell, 1966). The mechanisms by which environmental stresses affect plant metabolism, thereby reducing growth and development, are still not completely understood (Pessarakli, 1994). Furthermore, (GxE) interaction has been shown to reduce progress from selection (Comstock and Moll, 1963). 
An ideal cultivar would have both a high average performance over a wide range of environments plus stability. Finlay and Wilkinson (1963) used two values as a measure of both stability and adaptation. Cultivars with $b_{i}<1.0$ were considered above average in stability and specially adapted to unfavorable environments. Cultivars with $b_{i}=1.0$ were described as average in stability and either poorly or well adapted to all environments, depending upon the cultivar mean yield.

Table 6. Joint regression analysis for characters of the twelve genotypes under three sowing dates in the three growing seasons.

\begin{tabular}{|c|c|c|c|c|c|c|}
\hline \multirow[b]{2}{*}{$\begin{array}{l}\text { Source of } \\
\text { variation }\end{array}$} & \multirow[b]{2}{*}{ D.F } & \multicolumn{5}{|c|}{ Mean squares (M.S.) } \\
\hline & & $\begin{array}{l}\text { Days to } \\
\text { maturity }\end{array}$ & $\begin{array}{c}\text { Plant } \\
\text { height } \\
\text { "cm" }\end{array}$ & $\begin{array}{c}\text { Peduncle } \\
\text { length } \\
\text { "cm" }\end{array}$ & $\begin{array}{c}\text { Flag leaf } \\
\text { area "cm² " }\end{array}$ & $\begin{array}{c}\text { Straw } \\
\text { yield } \\
\text { "ton/ha" }\end{array}$ \\
\hline Genotypes & 11 & $77.33 * *$ & $1243.76 * *$ & $143.06 * *$ & $588.13 * *$ & $7.02 * *$ \\
\hline Env. + (G x Env.) & 96 & $260.59 * *$ & $94.37 * *$ & $55.94 * *$ & $105.11 * *$ & $15.83 * *$ \\
\hline a- Env.(linear) & 1 & $24090.86 * *$ & $6532.73 * *$ & $4213.93 * *$ & $8243.73 * *$ & $1276.57 * *$ \\
\hline $\begin{array}{l}\text { b- G x } \\
\text { Env.(linear) }\end{array}$ & 11 & $13.15 * *$ & $25.94 * *$ & 3.86 & $69.93 * *$ & $3.04 *$ \\
\hline c- Pooled dev. & 84 & $9.30 * *$ & $26.69 * *$ & $13.26 * *$ & $12.82 * *$ & $2.49 * *$ \\
\hline Pooled error & 198 & 2.40 & 10.85 & 4.48 & 8.06 & 1.61 \\
\hline
\end{tabular}

* and ** Significant and highly significant at 0.05 and 0.01 levels of probability, respectively.

\section{(1) Days to physiological maturity}

The joint regression analysis of variance Table (6) revealed that the component of Env. + (GXE) was highly significant for days to physiological maturity. In addition, partitioning Env. component mean squares and GXE component mean squares were highly significant. Indicating that the environments effect were linear function and the interaction of genotypes and environments were linear function for such trait.

The stability parameters $\left(b_{i}\right.$ and $\left.S^{2} d_{i}\right)$ and the mean performance $(\bar{x})$ of the individual genotypes are presented in Table (7). The regression coefficients $\left(b_{i}\right)$ for Sids 1, Giza 168, Sakha 94 and Line \# 5 were statistically equal unity and the deviations from regression $\left(S^{2} d_{i}\right)$ of those genotypes differed insignificantly from zero indicating that these genotypes may be considered as stable for such trait. Sids1 and Sakha 94 were considered specially adapted to heat stress environment because the regression coefficients of these genotypes were less than one $\left(b_{i}<1\right)$. However, according to Eberhart and Russell (1966), an ideal genotype would have both a high average performance over a wide range of environments plus stability, the most desirable genotypes based on the three stability parameters $\left(\bar{x}, b_{i}\right.$ and $\left.S^{2} d_{i}\right)$ were Giza 168 and Sakha 94 and Line \# 5 for days to physiological maturity because they had 
Table 7. Mean and estimated stability parameters of days to physiological maturity, plant height $(\mathrm{cm})$, peduncle length $(\mathrm{cm})$, flag leaf area $(\mathrm{cm} 2)$ and straw yield ( $t /$ ha) of each accession $(G)$ of wheat genotypes over the used environments $(E)$.

\begin{tabular}{|c|c|c|c|c|c|c|c|c|c|c|c|c|c|c|c|}
\hline \multirow{2}{*}{ Genotype } & \multicolumn{3}{|c|}{ Physiological maturity (days) } & \multicolumn{3}{|c|}{$\begin{array}{l}\text { Plant height } \\
\text { (cm) }\end{array}$} & \multicolumn{3}{|c|}{$\begin{array}{l}\text { Peduncle length } \\
(\mathrm{cm})\end{array}$} & \multicolumn{3}{|c|}{$\begin{array}{l}\text { Flag leaf area } \\
\left(\mathrm{cm}^{2}\right)\end{array}$} & \multicolumn{3}{|c|}{$\begin{array}{c}\text { Straw yield } \\
(\mathbf{t} / \mathrm{ha})\end{array}$} \\
\hline & Mean & $\mathbf{b}_{\mathbf{i}}$ & $S^{2} d_{i}$ & Mean & $\mathbf{b}_{\mathbf{i}}$ & $\mathbf{S}^{2} \mathbf{d}_{\mathrm{i}}$ & Mean & $\mathbf{b}_{\mathbf{i}}$ & $\mathbf{S}^{2} \mathbf{d}_{\mathrm{i}}$ & Mean & $\mathbf{b}_{\mathbf{i}}$ & $\mathbf{S}^{2} \mathbf{d}_{\mathrm{i}}$ & Mean & $\mathbf{b}_{\mathbf{i}}$ & $\mathbf{S}^{2} \mathbf{d}_{\mathrm{i}}$ \\
\hline Sids 1 & 135.96 & 0.995 & 2.416 & 106.30 & 1.312 & $37.481^{* *}$ & 35.90 & 1.071 & $21.275^{* *}$ & 49.24 & 1.488 & 37.921** & 13.17 & 1.090 & 0.958 \\
\hline Giza 168 & 133.63 & 1.007 & 3.926 & 94.30 & $0.706 *$ & 6.969 & 37.53 & 0.934 & 5.835 & 40.40 & 0.892 & 14.610 & 11.19 & 1.005 & 1.647 \\
\hline Line \# 3 & 133.45 & 1.020 & $7.886^{* *}$ & 92.37 & 0.926 & $24.906 *$ & 30.74 & 1.217 & $16.890 * *$ & 37.60 & $0.655^{* *}$ & 3.054 & 11.60 & $0.729 *$ & 1.118 \\
\hline Sakha 94 & 131.26 & 0.971 & 3.089 & 103.44 & 1.329 & $41.065 * *$ & 36.42 & 1.071 & 4.625 & 37.67 & $0.768^{* *}$ & 1.944 & 11.86 & 1.031 & 2.766 \\
\hline Line \# 5 & 134.00 & 1.029 & 3.017 & 93.22 & 1.057 & 14.774 & 33.62 & 1.073 & $17.581^{* *}$ & 41.57 & 0.973 & $24.516 * *$ & 11.98 & 0.751 & $5.561 * *$ \\
\hline$\underset{10}{\text { Gemmeiza }}$ & 136.89 & 0.977 & $3.037 * *$ & 88.67 & 0.732 & 16.002 & 33.12 & 0.999 & 6.589 & 38.45 & 0.813 & 13.566 & 12.12 & 1.084 & 1.904 \\
\hline Line \# 7 & 137.11 & 0.876 & $10.225 * *$ & 90.30 & 0.801 & 19.440 & 34.74 & 1.054 & 1.702 & 35.67 & 0.872 & 6.883 & 12.08 & 0.897 & 0.621 \\
\hline Line \# 8 & 135.78 & 0.862 & $18.009 * *$ & 91.89 & 1.237 & 7.395 & 35.31 & 0.915 & $20.438^{* *}$ & 37.76 & 1.047 & 14.165 & 12.14 & 0.920 & 0.545 \\
\hline Gemmeiza 9 & 135.93 & 0.973 & $9.452^{* *}$ & 105.41 & 0.989 & 71.536** & 36.30 & 0.908 & $18.562^{* *}$ & 39.36 & 0.789 & 5.727 & 12.64 & 1.131 & $4.162^{*}$ \\
\hline El-Nelin & 133.67 & 1.066 & $12.391^{* *}$ & 106.15 & 1.042 & 20.801 & 39.23 & 0.944 & 3.421 & 44.69 & 0.704 & 15.632 & 11.60 & 1.064 & 3.110 \\
\hline Debeira & 135.00 & 1.067 & $8.056^{* *}$ & 103.33 & 1.087 & 22.417* & 37.03 & 0.821 & 7.220 & 45.80 & $1.426^{*}$ & 10.999 & 12.19 & 1.349 & 5.353 \\
\hline HD2501 & 134.04 & 1.159 & $26.104 * *$ & 100.56 & 0.784 & $37.434 * *$ & 37.49 & 0.993 & $34.954 * *$ & 49.20 & $1.573^{* *}$ & 4.859 & 11.85 & 0.948 & 2.169 \\
\hline Grand mean & 134.73 & -- & -- & 97.99 & -- & -- & 35.62 & -- & -- & 41.46 & -- & -- & 12.04 & -- & -- \\
\hline L.S.D 0.05 & 0.70 & -- & -- & 1.53 & -- & -- & 0.97 & -- & -- & 1.30 & -- & -- & 0.53 & -- & -- \\
\hline
\end{tabular}

* and ** Significant and highly significant at 0.05 and 0.01 levels of probability, respectively. 
desired performance (earliness), $b_{i}$ did not differ significant from unity and least deviation from regression did not differ significantly from zero. These genotypes may have genetic systems controlling earliness and able to work consistently over environments. These results are in line with those reported by Kheiralla et. al. (1997), Tawfelis (2006 a) and Seleem (2007).

\section{(2) Plant height (cm)}

The joint regression analysis of variance Table (6) revealed that the component of Env. $+(\mathrm{G} \times \mathrm{E})$ was highly significant for plant height. In addition, partitioning Env. component mean squares and GXE component mean squares were highly significant indicating that the environmental effect and the interaction of genotypes and environments were linear function for such trait.

The stability parameters $\left(b_{i}\right.$ and $\left.S^{2} d_{i}\right)$ and the mean performance $(\bar{x})$ of the individual genotypes are presented in Table (7). The regression coefficients $\left(b_{i}\right)$ for Line \# 5, Gemmiza 10, line \# 7, line \# 8 and El-Nelin were statistically equal to unity and the deviations from regression $\left(S^{2} d_{i}\right)$ of those genotypes were also insignificantly different from zero, indicating that these genotypes may be considered as stable for such trait. Gemmiza 10, and Line \# 7 were considered specially adapted to heat stress environment because the regression coefficients of both genotypes were insignificantly from one and less than unity $\left(b_{i}<1\right)$. Otherwise, the " $b_{i}$ " was insignificantly from one and more than unity $\left(b_{i}>1\right)$ in Line \# 5 and Line \# 8 which appeared to be more adapted to favorable environments. The most desirable genotypes based on the three stability parameters $\left(\bar{x}, b_{i}\right.$ and $\left.S^{2} d_{i}\right)$ were Line \# 5, Gemmiza 10, Line \# 7 and Line \# 8 for plant height because they had desired performance, $b_{i}$ did not significantly differ from unity and least deviation from regression did not significantly differ from zero. These results are in line with those reported by Ismail (1995) and Seleem (2007).

\section{(3) Peduncle length (cm)}

The joint regression analysis of variance in Table (6) revealed that the component of Env. + $(G \times E)$ was highly significant for peduncle length. In addition, partitioning Env. component mean squares was highly significant, while GXE component mean squares was not significant. Indicted that the environments effect were linear function but the interaction of genotypes and environments were not linear function for such trait.

The stability parameters $\left(b_{i}\right.$ and $\left.S^{2} d_{i}\right)$ and the mean performance $(\bar{x})$ of the individual genotypes are presented in Table (7). The regression coefficients $\left(b_{i}\right)$ for Giza 168, Sakha 94, Gemmiza 10, line \# 7, El-Nelin and Debeira were statistically equal unity and the deviations from regression $\left(S^{2} d_{i}\right)$ of those genotypes were also insignificantly different from zero, indicating that these genotypes may be considered as stable for such trait. Giza 168, Gemmiza 
10, El-Nelin and Debeira were considered specially adapted to heat stress because the regression coefficients of these genotypes were less than one $\left(b_{i}<1\right)$. These results are in line with those reported by Tawfelis (2006) and Seleem (2007).

\section{(4) Flag leaf area}

Stability analysis of variance of flag leaf area (Table 6) indicated highly significant mean squares of wheat genotypes, revealing that wheat genotypes were genetically different for genes controlling flag leaf area. Highly significant environment $+(\mathrm{G} \times \mathrm{E})$ component and environment (linear) mean squares, indicating that flag leaf area was highly influenced by the combination of environmental components ( season and sowing dates). Highly significant GXE (linear) interaction was shown for flag leaf area, indicating that wheat genotypes responded differently to various environments.

The stability parameters $\left(b_{i}\right.$ and $\left.S^{2} d_{i}\right)$ and the mean performance $(\bar{x})$ of the individual genotypes are presented in Table (7). The regression coefficients $\left(b_{i}\right)$ for Giza 168, Gemmeiza 10 , line \# 7, line \# 8, Gemmeiza 9 and El-Nelin were statistically equal unity and the deviations from regression $\left(S^{2} d_{i}\right)$ of those genotypes were also non-significantly differ from zero, indicating that these genotypes may be considered as stable for such trait. Gemmeiza 10, line \# 7, Gemmeiza 9 and El-Nelin were considered specially adapted to heat stress environment because the regression coefficients of this genotype was less than one $\left(b_{i}<1\right)$ and stable genotype for flag leaf area.

\section{(5) Straw yield (t/ha)}

The joint regression analysis of variance in Table (6) revealed that the component of Env. + (G×E) was highly significant for straw yield. In addition, partitioning Env. component mean squares and GXE component mean squares were highly significant and significant, respectively. Indicted that the environments effect and the interaction of genotypes and environments were linear function for such trait.

The stability parameters $\left(b_{i}\right.$ and $\left.S^{2} d_{i}\right)$ and the mean performance $(\bar{x})$ of the individual genotypes are presented in Table (7). The regression coefficients $\left(b_{i}\right)$ for genotypes Sids 1 , Giza 168, Sakha 94, Gemmeiza 10, line \# 7, line 8, El-Nelin, Debeira and HD 2501were statistically equal unity and the deviations from regression $\left(S^{2} d_{i}\right)$ of those genotypes were also nonsignificantly differ from zero, indicating that these genotypes may be considered as stable for such trait. Otherwise, the " $b_{i}$ " was insignificantly from one and more than unity $\left(b_{i}>1\right)$ in Sids 1 which appeared to be more adapted to favorable environments. These results are in line with those reported by Ismail (1995), Tawfelis (2006) and Seleem (2007). 


\section{Heat susceptibility index (HSI)}

The heat susceptibility indices "HSI" based on straw yield for genotypes are presented in (Table 8). These indices were used to estimate the relative stress injury (heat) because it is accounted as variation in yield potential and stress intensity. Higher values indicated higher degree of susceptibility and vice versa (Fischer and Maurer, 1978).

It is worthy to mention here that $H S I$ provides a measure of tolerance based on minimization of yield loss under stress rather than non-stress yield per se. Therefore, the stress tolerant genotypes as defined by $\mathrm{S}$ values do not need to have a high yield potential. These genotypes should contain resistance (tolerance) mechanisms, which may need to be incorporated into germplasm with higher yield potential for development of high yielding stress tolerant cultivars.

Table 8. Straw yield ( $t / h a$ ) under normal (D1) and late sowing dates (D3) and heat susceptibility index (HSI) over all environments between $1^{\text {st }}$ and $3^{\text {rd }}$ sowing dates for twelve wheat genotypes.

\begin{tabular}{|c|c|c|c|}
\hline Genotype & Date 1 & Date 3 & HSI \\
\hline Sids 1 & 15.64 & 10.82 & 1.04 \\
\hline Giza 168 & 13.45 & 9.33 & 1.03 \\
\hline Line \# 3 & 13.59 & 9.93 & 0.91 \\
\hline Sakha 94 & 14.39 & 9.54 & 1.13 \\
\hline Line \# 5 & 13.94 & 9.76 & 1.01 \\
\hline Gemmeiza 10 & 14.79 & 10.16 & 1.05 \\
\hline Line \# 7 & 14.07 & 10.18 & 0.93 \\
\hline Line \# 8 & 14.28 & 10.11 & 0.98 \\
\hline Gemmeiza 9 & 14.68 & 10.63 & 0.93 \\
\hline El-Nelin & 13.72 & 9.73 & 0.98 \\
\hline Debeira & 15.12 & 9.98 & 1.14 \\
\hline HD2501 & 13.65 & 10.22 & 0.85 \\
\hline Grand mean & 14.28 & 10.03 & 1.00 \\
\hline
\end{tabular}

Fisher and Wood, (1979) concluded that HSI was used to estimate stress injury. Low stress susceptibility $(\mathrm{HSI}<1)$ is synonymous with higher stress tolerance. Results in (Table 8) indicated that the values of $H S I$ over all three years ranged from 0.85 for HD 2501 to 1.14 for genotype Debeira. The genotypes Line \# 3 , Line \# 7, Line \# 8 Gemmeiza 9 , El-Nelin and HD 
2501 produced low heat susceptibility index $(0.91,0.93,0.98,0.930 .98$ and 0.85$)$ and straw yields of $9.93,10.18,10.11,10.63,9.73$ and 10.22 t/ha for the six genotypes, respectively. $A$ superior genotypes for heat tolerance would give the least values of heat susceptibility index (HSI < 1) and high straw yield under heat stress. Therefore, these genotypes could be considered as promising genotypes in breading wheat program for heat stress.

\section{REFERENCES}

1. Abdel-shafi, A. M., A. M. Abdelghani, M.B. Tawfelis, M.G. Mossad and M. KH. Moshraf. 1999. Screening of wheat germplasm for heat tolerance in Upper Egypt. Egypt J. Plant Breed., 3:77-87.

2. Al-Otayk, S. M. 2010. Performance of yield and stability of wheat genotypes under high stress environments of the central region of Saudi Arabia. JKAU: Met., Env. \& Arid Land Agric. Sci., Vol. 21, No.1, pp: 81-92 .

3. Comstock, R. E. and R. H. Moll. 1963. Genotype environment interactions. In W.D. Hanson and H.F. Robinson (ed.) Statistical Genetics and Plant Breeding, Proc. Natl. Acad. Sci. NRC. Pub. No. 982: 164-196.

4. Eberhart, S. A. and W. A. Russell. 1966. Stability parameters for comparing varieties. Crop Sci., 6: 36-40.

5. El Morshidy, M. A., K. A., Khieralla, A. M. Abdelghani and A. A. Abd El- Kareem. 2001. Stability analysis for earliness and grain yield in bread wheat, The 2 Plant Breed. Conf. October 2, Assiut Univ., pp: 199-217.

6. Finlay, K. W. and G. N. Wilkinson. 1963. The adaptation in plant breeding programme. Australian J. Agr. Res. 14:742-754.

7. Fischer, R. A. and J. T. Wood. 1979. Drought resistance in spring wheat cultivars .II-Yield associations with morpho-physiological traits. Assiut. J. Agric. Res. 30: 1001 - 20 .

8. Fischer, R.A. and R.O. Maurer. 1978. Drought resistance in spring wheat cultivars. I: Grain yield responses. Aust. J. Agric. Res., 29: 897-912.

9. Gomez, K. A. and A. A. Gomez. 1984. Statistical Procedures for Agricultural Research. John Wiley and Sons. Inc. New York, USA.

10. Ismail, A. A. 1995. The performance and stability of some wheat genotypes under different environments. Assiut J. Agric. Sci., 26: 15-37.

11. Kheiralla, K. A., A. A. Ismail and G. R. El-Nagar. 1997. Drought tolerance and stability of some spring wheat cultivars. Assiut J. Agric. Sci. 28(1):75-88. 
12. Montgomery, E. G. 1911. Correlation studies of corn. Nebraska, Agric. Exp., Vol.24 ${ }^{\text {th }}$, AM. Rept. Agron. J. 53: 187-188.

13. Pessarakli, M. 1994. "Handbook of Plant and Crop Stress" Marcel Dekker, Inc., New York, Basel, Hong Kong.

14. Seleem, S. A. 2007. Analysis of phenotypic stability for grain yield and its components in bread wheat. J. Agric. Sci. Mansoura Unv., 32(4):2403-2420.

15. Sial, M. A., M. A. Arain, S. Khanzada, M. H. Naqvi, M. U. Dahot and N. A. Nizamani. 2005. Yield and quality parameters of wheat genotypes as affected by sowing dates and high temperature stress. Pakistan J. of Bot., 37(3):575-584.

16. Tammam, A. M. and M. B. Tawfelis. 2004. Effect of sowing date and nitrogen fertilizer levels in relation to yield components of durum wheat (Triticum turgidum var. durum) under Upper Egypt environments. J. Agric. Sci. Mansoura Univ., 29(10):5431-5442.

17. Tawfelis, M. B. 2006. Stability parameters of some bread wheat genotypes (Triticum aestivum L.) in new and old lands under Upper Egypt conditions. Egypt J. Plant Breed., 10 (1):223-246. 


\section{الاختلافات الوراثية في تحمل قمح الخبز للإجهاد الحراري تحث ظروف منطقة مصر العليا}

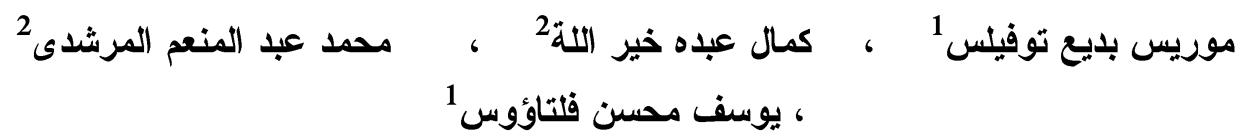

$$
\begin{aligned}
& \text { ا ـ قسم بحوث القفح - معرة بحوث المحاصيل الحقلية - مركز البحوث الزراعية - مصر }
\end{aligned}
$$

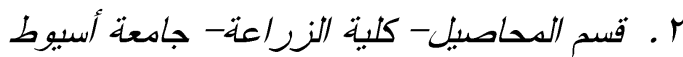

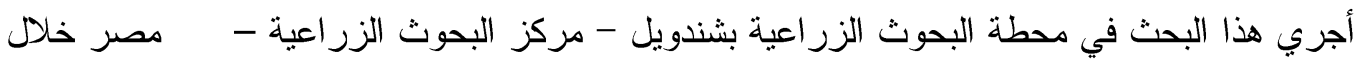
المو اسم الزراعية الثلاثة 2004 / 2005 ، 2005/ 2006 ، 2006/ 2007 وكان الهدف من الدراسة تقييم

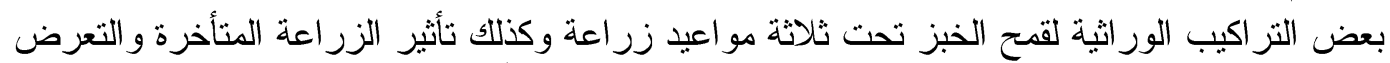

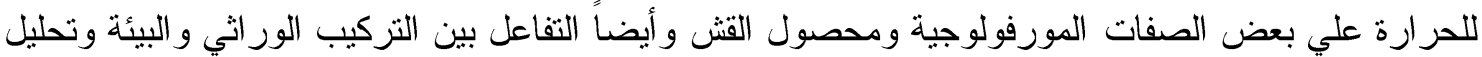
الثبات ومعامل الحساسية للحرارة.

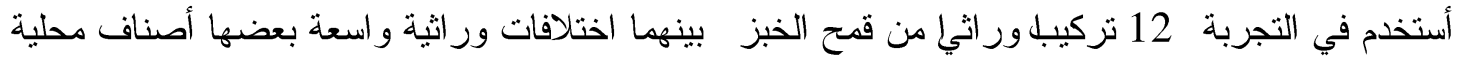
و أخري مستوردة، زرعت هذه الأصناف و السلالات في ثلاثة مو اعيد زر اعية، الموصي به (ل

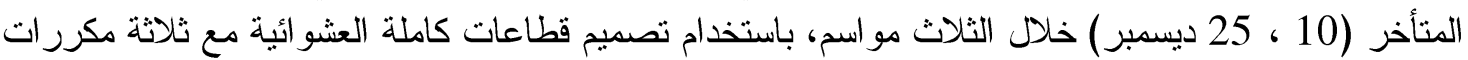
في كل ميعاد زر اعة.

وقد تمت دراسة عدد الأيام من الزر اعة حتى النضدج الفسيولوجي ، طول النبات، طول حامل السنبلة، مساحة ورقة العلم ومحصول القش طن/هكتار ـ وقد أظهرت النتائج استجابات مختلفة للتر اكيب الور اثية من بيئة

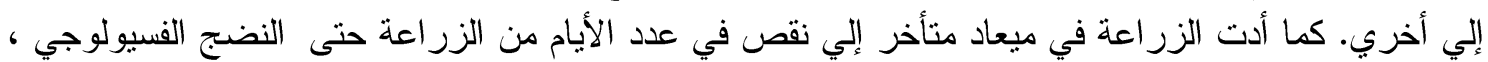

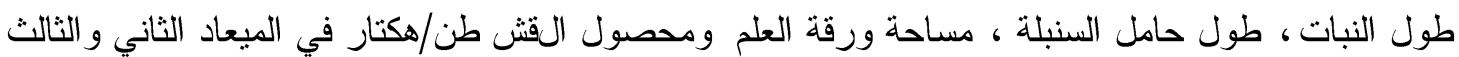

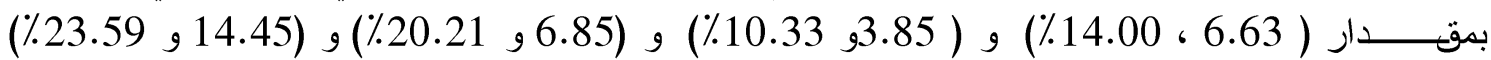
و ( 17.37 و 29.76٪ ) بالمقارنة بالزر اعة في الميعاد الأول علي التزتيب. تنتير هذه النتائج إلى أن التز اكيب الور اثية تباينت في استجابتها للظروف البيئية مما يوضح أهمية تقييم التزر اكيب الور اثية تحت بيئات مختلفة بغرض تحديد أفضل التر اكيب الور اثية لهذه البيئات. أظهر تحليل تباين الانحدار فروقا عالية المعنوية بين التراكيب الور اثية لكل الصفات المدروسة. علاوة

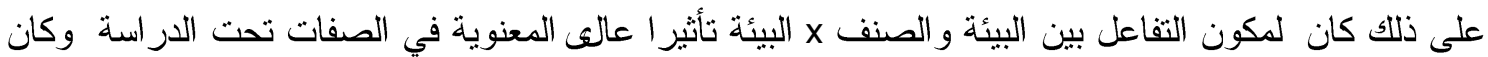

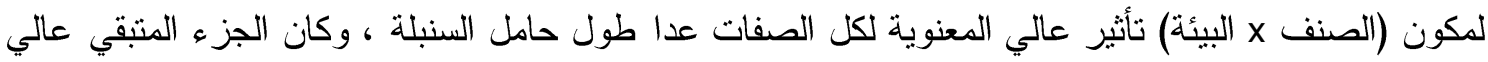

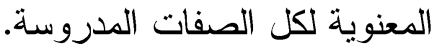

أكدت النتائج ضرورة استخدام كل من منوسط أداء التركيب الور اثي ومقياس الثبات الخاصة به معا للتوصية باستخدام أي تركيب ور اثي في بيئات مختلفة.

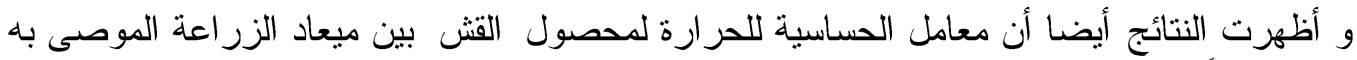

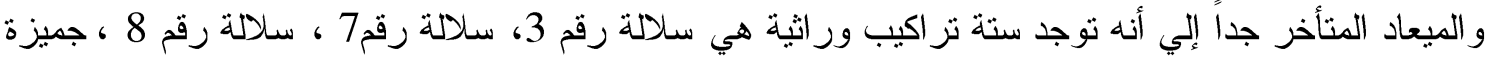

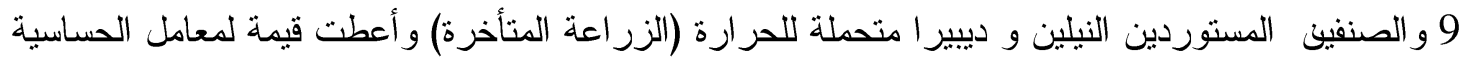

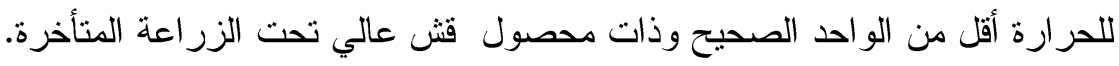

